\title{
LISTY ZNAD ZATOKI ŚWIĘTEGO FRANCISZKA
}

\author{
Eugeniusz S. KRUSZEWSKI (Instytut Polsko-Skandynawski, Kopenhaga)
}

Dwie pary małżeńskie, przyjaciele, którzy przez dwanaście lat byli blisko siebie w Stanach Zjednoczonych, a po zakończeniu służby duńskiej pary dyplomatycznej utrzymywali ze sobą bardzo bliski kontakt za pośrednictwem korespondencji. Ich rodowe korzenie były różne, ale należeli do tego samego pokolenia, patriotyzmem i z doświadczeniami drugiej wojny światowej w Polsce.

Listy, o których tu mowa, przychodziły z San Francisco do Svaneke, małej miejscowości na bałtyckiej wyspie Bornholm, gdzie na emeryturze osiedliło się duńskie małżeństwo. Ich treść odzwierciedla głębokie więzy, jakie zawiązały się między nimi. Dziesięcioletni okres między rokiem 1985 a 1995, którego listy dotyczą, to okres schyłkowy ich drogi życia.

Osobami tego dramatu są:

Hanna Gordziałkowska c. Bronisława i Anieli neé Czarnowska (18 XII 1918 Warszawa - 12 VII 1998 San Francisco), pseudonim artystyczny „Kali”. Po trzech latach studiów w Akademii Sztuk Pięknych w Warszawie, gdzie była uczennicą Tadeusza Pruszkowskiego, wybuchła II wojna światowa. Zamiast dalszych studiów podjęła walkę z okupantem. Jako porucznik Armii Krajowej wzięła udział w Powstaniu Warszawskim, a następnie trafiła do niemieckiego obozu jenieckiego. W 1945 roku ze strefy sowieckiej przedostała się do Belgii i kontynuowała studia w Królewskiej Akademii Sztuk Pięknych w Brukseli. Tu spotkała swego przyszłego męża, Henryka Weynerowskiego, byłego więźnia, którego poślubiła w 1950 roku, i razem z nim emigrowała do Kanady. Po trzech latach oczekiwania na wizę amerykańską w 1953 roku wyjechali do Stanów i osiedlili się w Kalifornii. W 1958 roku otrzymali obywatelstwo USA. Hanna miała o cztery lata starszą siostrę Marię, 1.voto Wójtowicz, 2.voto Woytowicz-Wyatt, zamieszkałą również w USA, z synem Wyatt (Santa Rosa, California).

Henryk K. Weynerowski (1901-1988), był synem przedsiębiorcy, juniorem, z Bydgoszczy. W czasie drugiej wojny światowej więzień niemieckich władz okupacyjnych i członek A.K.

Muza księżniczka Czagadajew (1922 Ryga - 2007 Svaneke, Bornholm, Dania). Po rozwodzie rodziców wyjechała z matką Łotyszką do Wolnego Miasta Gdańska, gdzie, 
ochrzczona przez ks. Trzebiatowskiego w katolickim kościele św. Jerzego w Sopocie, otrzymała imię Maria. Została adoptowana przez ojczyma Kaliańskiego. W Gdańsku uczęszczała do szkół i rozpoczęła pracę zawodową. W czasie drugiej wojny światowej zaprzyjaźniła się z duńskim dyplomatą J.L.F. Mogensem, i razem z nim została członkiem „Gryfu Pomorskiego” w Gdyni.

Jørgen Lønborg Friis Mogensen (1909-2000) urodzony w Danii, ale wychowany w Polsce, gdzie ojciec był dyrektorem cementowni w Bonarce k. Olkusza. Uczęszczał do Gimnazjum im. Kazimierza Wielkiego w Olkuszu i tam uzyskał świadectwo maturalne. Następnie razem z polskimi kolegami studiował w Wiedniu i Grenoble. W 1935 roku wstąpił do duńskiej służby zagranicznej i pełnił służbę w poselstwie Danii w Warszawie przed (1935-1939) i po wojnie (1946-1952). W czasie wojny był konsulem duńskim konsulacie honorowym w Gdańsku (1941-1944) i członkiem „Gryfa Pomorskiego” w Gdyni. W wyniku zdrady został aresztowany i osadzony w obozie koncentracyjnym Dachau i Flossenbürg. Po wojnie podjął służbę w duńskiej dyplomacji i przebywał na placówkach w Stanach Zjednoczonych A.P., Republice Południowej Afryki i Rodezji oraz Australii (1953-1978). Służbę, po 44 latach, zakończył w 1979 roku.

W Danii zachowała się część korespondencji, która z San Francisco kierowana była do adresatów na Bornholmie. Znajdziemy tam kilka wątków, które zwracają naszą uwagę, np.: polityka, język, jakim posługuje się „amerykańska” strona, oraz ich odczucia wobec centrum polskiej emigracji niepodległościowej w Londynie. Z uwagi na to, że San Francisco było mekką intelektualnego środowiska polskiego, a mamy tu na myśli m.in. obecność takich osobistości jak historyk Jerzy Lerski (1917-1992), poetka i pianistka Alicja Pomian-Pożerska Matulewicz (1910-2003) oraz historyk i dyplomata Witold S. Sworakowski (1903-1979), uwagi są adekwatne. Ich treść rzuca także światło na stosunki polskiego Londynu wobec polskiej elity intelektualnej w Ameryce. Dodać należy, że wspomniane wyżej osoby znały się i utrzymywały przez długie lata kontakty osobiste i korespondencyjne.

Listy wydają się ciekawe $\mathrm{z}$ uwagi na środowisko tak nadawców, jak i adresatów. Z jednej strony Polacy, emigranci po zakończonej wojnie w 1945 roku, a z drugiej Polacy z wyboru, którzy utożsamiali się z polską kulturą, a jednocześnie żyli w tej samej epoce $z$ podobnymi doświadczeniami. Jedni i drudzy po ciężkich przeżyciach wojennych (m.in. pobyt $\mathrm{w}$ niemieckich obozach koncentracyjnych), mieli na ogół podobny punkt widzenia na sprawy i dzieje tego świata, w tym opinie o pierwszoplanowych politykach polskiego państwa na uchodźstwie.

Pamiętam, że będąc po raz pierwszy w Londynie w 1970 roku, zwróciłem uwagę na egocentryzm polskiego Londynu. Widoczny był na wielu płaszczyznach, ale najbardziej uwidaczniało się to w codziennej prasie — wszystko obracało się wokół londyńskiego ,podwórka”.

Uważaliśmy, że znaczne poparcie polskiego społeczeństwa w świecie zachodnim dla prawowitych władz polskich i jego działalność na rzecz polskiego państwa na uchodźstwie w poszczególnych krajach należało silniej eksponować w Londynie.

Mimo różnicy poglądów polityków niepodległościowej emigracji, a także przywódców Polonii, wyrażało ono dążenie narodu do suwerenności naszego kraju. Postulat pozostał w zasadzie bez echa. Owszem, było kilka wyjazdów premiera czy ministrów na kontynent amerykański i do Australii, ponadto na przełomie lat 70. i 80. wprowadzono w „Dzienniku Polskim i Dzienniku Żołnierza” stronę z informacjami 
o działalności Polaków w różnych krajach europejskich. Jednakże wcześniejsze, wieloletnie zaniedbania zniechęcały poszczególne środowiska do eksponowania siebie na łamach londyńskiej prasy. Ich działalność jest udokumentowana w lokalnej prasie i biuletynach związków i stowarzyszeń, a była ona często większa od innych, działających na terenie Wielkiej Brytanii.

Z drugiej strony przynależność partyjna prezesów organizacji rzutowała na politykę organizacji i stowarzyszeń, takich jak Związek Dziennikarzy RP i Związek Pisarzy Polskich na Obczyźnie, a także organizacji zawodowych i społecznych, którym przewodzili członkowie np. Stronnictwa Narodowego, Polskiej Partii Socjalistycznej (trzy frakcje) czy Polskiego Ruchu Wolnościowego „Niepodległość i Demokracja”, którzy nie zawsze sympatyzowali z działalnością prawowitych władz. 


\title{
LISTY $^{*}$
}

\author{
1.
}

[Tekst na odwrocie fotografii: Henryk Weynerowski, Hola Żyrońska-Messel, Kali]

Ottawa 14 X 1963

Serdecznie dziękujemy za kartkę, która została uzupełniona ustnie przez Tenego i zasyłamy bardzo wiele najlepszych pozdrowień Drogiemu polskiemu Duńczykowi i jego Pani. Na odwrocie dla informacji, to troje starych gunoblończyków - Hola Żyrońska obecnie Messell, która przyjechała z Norwegii tego lata do US i Kanady i spędziła u nas tydzień.

Adam

Wiele serdeczności dołączam. Byłoby bardzo miło odświeżyć starą przyjaźń osobistym bałakiem może tu kiedyś dojedziecie tak, jak to zrobiła Hola.

Bardzo mocno całuję Was Oboje! W tych dniach napiszę obszerniejszy list.

2.

[San Francisco] 7-go września 1984

Nasi bardzo a bardzo Kochani!

Darujcie, proszę, brak odpowiedzi na Wasz tak serdeczny list i książkę z końca marca, która przydała się wielce podczas coraz czarniejszych „,białych nocy”. I dalej trudno mi zebrać się na jakieś cnotliwe pisadło, pozbawione żalów i utyskiwań jakich my nie lubimy wysyłać - a Wy odczytywać.

Jakże tu jednak mówić do Najbliższych o pogodzie, wyborach prezydenta, czy pomniejszych wstrząsach kalifornijskich, kiedy bezpośrednia ziemia i próg naszego Domku z każdym dniem staje się bardziej chwiejny i coraz rzadziej przestępowany. A tak go ostatnio zdążyliśmy jeszcze wypieścić „na wysoki połysk”, że smutno myśleć — w czyje ręce wpadnie po nas i kto to doceni??? (Przed rokiem wymalowaliśmy dom zewnątrz, a ja przed dwoma - w środku; wstawiliśmy „ręcznie kute”, wedle mego rysunku, żelazne kraty do okien i drzwi, a la meksykańskie i przez Meksykańczyka uskutecznione; w patio szaleją bougenville ${ }^{1}$ : przed oknem kuchennym, w okrągłych deseniach odstających od muru krat - doniczki ,impaciences”, czy jak się one nazywają, w kolorach rozpalonego ogniska „domowego"... Kto ten ogień i serdeczne ciepło po nas zechce - i - potrafi podniecać? A niech to kaczka kopnie!

\footnotetext{
*Wszystkie listy mają zachowaną oryginalną pisownię [przyp.red.].

${ }^{1}$ Bugenwilla, kącicierń (Bougainvillea Comm. ex Juss.), rodzaj roślin z rodziny dziwaczkowatych. Należy do niej od czterech do 18 gatunków roślin pnących.
} 
No więc, żeby Was nie obrażać mówieniem o pogodzie: ze zdrowiem naszego Henryśka jest ź 1 e i — coraz gorzej. Na poprawę liczyć już nie można. Połamany krzyż pęka coraz dalej; prawie wszystkie zęby także. Bóle ogromne. Prawie nie wstaje już z łóżka. Nawet silne dozy cholernego „Percodanu” przestają działać, a morfinę pozostawia się na... ostatnią „ostateczność”. (...)

Trudno by Wam było poznać naszego Henryśka: waga prawie że moja, wzrost także. Nie może (i nie chce) nic jeść. Staram się chyba bardziej niż Muzka - przygotować $\mathrm{Mu}$,specjalijki”, tak ongiś lubione... Weźmie raz widelec, czy łyżeczkę — i... „,nie gniewaj się, Hanulko, nie mogę".

Ostatnio odżywiam Go, jak koliberka, wodą z miodem rano, a wieczorem „goglem-moglem" czyli ubitym źółtkiem z cukrem i śmietanką. Jak długo będzie to połykał - nie wiem? Już dzisiaj zaczęło się znowu: „,mój Hanuleczku, moje najdroższe Haniątko - ja chcę, ale doprawdy nie mogę...”, „Bądź tylko ze mną!”, „Daj mi słowo, że nie odejdziesz przede mną, bo tylko ta myśl mnie dręczy".

Daję Mu „słowo”, mimo pewnych kłopotów, pogarszającej się anginy pectoris, na które nie mogę mieć żadnego wpływu w ogóle, a w zaistniałej sytuacji w szczególności. Wiem, że dotrzymam. Nie ma sprawy. Chcę, żeby wiedział i wierzył, że odejdziemy razem. I tak też musi być. Amen.

[przerwa w pisaniu]

Którejś nocy, widać po przeczytaniu jakiegoś artykułu w „Przekroju” o rocznicy Hiroszimy $^{2}$, czy innym katakliźmie nieoczekiwanym, gładzi mnie po ramieniu: „Hanulek śpisz? — „Nie”. ”Bo wiesz, tak sobie pomyślałem: gdyby to nie dotyczyło takiej masy innych ludzi, to modliłbym się chyba o trzęsienie ziemi. Wówczas odlecielibyśmy razem i nie miałbym wyrzutów sumienia za mój egoizm, że chciałbym być pierwszy...". Nie powiedziałam $\mathrm{Mu}$, oczywiście, że i z tych samych względów przeładowanego ludźmi samolotu — podobne myśli powstrzymywały mnie od identycznej modlitewki w naszej drodze do Kanady i w Toronto, jakoś tę ostatnią eskapadę wytrzymał. Tym nie mniej zdawałam sobie sprawę z najbliższej przyszłości i wiszących nad nami problemów.

No to koniec utyskiwań — przechodzimy do „pogody”, czyli spraw nieistotnych. Już drugi rok nic nie maluję. Mała szkoda. I tak mam za dużo obrazów, bez możliwości zorganizowania jakiejś wystawy a tym samym, i — rzecz jasna — sprzedaży. Głównym i zasadniczym problemem (dosłownie zciągającym sen z oczu) jest tzw. tabliczka mnożenia, dzielenia i - dodawania.

O tym, abym wygłupiła się w istniejących Krajowych „warunkach” i przekazała je testamentarnie do Polski — nie ma mowy. Bez względu na sympatyczne propozycje takich-i-owakich naiwnych entuzjastów o wielkim Patriotyźmie.

Chyba już Wam pisałem (nie wspomnę), o kilometrach wytutkanej na maszynie korespondencji ze wszelkimi polonijnymi INSTYTUCJAMI; tak w Stanach, jak i Szwajcarii. (Londynu nie ruszam, bo nie ma sensu; niestety, ci panowie i panie, odnoszą się do Amerykańskich współbraci - literatów, artystów, etc. - z wybitną niechęcią).

Francja także odpada, bo alfa-omega Czapski ${ }^{3} \mathrm{z}$ „Kultury” — znieść mnie nie może, a bez Jego, chwalebnej opinii — nikt nad Sekwaną nie przyjmie (nawet za darmo) moich obrazków. No — to zrób mu dziecko.

\footnotetext{
${ }^{2}$ Hiroszima i Nagasaki, dwa miasta, na które w dniu 6 sierpnia 1945 r. zostały zrzucone bomby atomowe.

3 Józef Czapski (1896-1993), artysta malarz, pisarz, major W.P., przeżycia z pobytu w Sowietach opisał w książkach Wspomnienia starobielskie i Na nieludzkiej ziemi. Od 1946 r. w Paryżu, współtworzył paryską „Kulturę”.
} 
Wiesz Jorgenie, przypomina mi się ta bajka Lafontaina ${ }^{4}$ o ojcu i synie, prowadzących na targ osiołka (miałam w dzieciństwie taką książkę z prześlicznymi ilustracjami na płótnie-papierze): jak-i-co by nie zrobili wedle rady kumów i kumoszek — wszystko było złe... albo żałowali osiołka, albo ojca, albo syna... No, to właśnie, i ja nie wiem, jak mam wszystkie kumoszki zadowolić? A, ostatecznie, czas mi się skraca z każdym dniem i, jak pragnę kichnąć, nie mam już zielonego pojęcia komu przekazać mam ten Mój i Henryśka 40-to letni dorobek.

Jeśli coś przyjdzie Ci do kochanego łebka - napisz. Znowu siądę do maszynki i będę kukać (a Henryś będzie wołał z sypialni: „Hanulka, gdzie jesteś”) [przerwa w pisaniu]

Jeśli byś mógł, Jorgenie Drogi, rzucić czasami kilka słów ciepłych na naszą Świętokrzyską Górkę - zrobisz i mnie, i Henrysiowi wielką frajdę. Jesteś dyplomatą i potrafisz, przy swojej „polskiej” serdeczności i pisarskim talencie, ominąć jakąkolwiek wzmiankę na temat mego listu i niepokoju o zdrowie Henryśka. Pisz, proszę, jak dotychczas, że... czekacie na nasz przyjazd i obopólną radość z kulinarnych wyczynów niezrównanej Muzki. Dziękuję.

Nie zaniechaj jednak podać prawdziwe sprawozdanie o Was samych. Jesteście już ostatnimi naszymi PRAWDZIWYMI PRZYJACIOŁMI i wszystko, co Was dotyczy jest i dla nas bardzo ważne. I: najważniejsze!! Na Polskę, Warszawę itp. nie trać czasu i miejsca w „par-avionie”. Chcemy wiedzieć o Was. Obecny „Kraj” i wszelkie tamtejsze stosunki - znamy na pamięć (parę tygodników krakowsko-warszawskich plus „Kultura” paryska - trzyma nas na chodzie). Można powiedzieć, że jesteśmy zorientowani na tamtejsze tematy nawet bez czarnych okularów z epoletami...

„Do widzenia”, Kochani — bądźcie przynajmniej Wy zdrowi, Kochamy Was całym sercem, zawsze Wasi Henryk i Kali

3 .

San Francisco, 18-ty - 28-my 1985[?]

Nasi bardzo a bardzo Kochani!

Chyba po raz pierwszy w życiu zdarza mi się odpisywać na 3 (trzy!) kolejne listy w ogóle a od tak bliskich sercu — w szczególności. Darujcie, proszę, i wybaczcie przyjacielskim zrozumieniem.

Choroba Henryśka (3 długie pobyty w szpitalu) trwa już od kilku lat. Ostatni zaś rok był i jest nadal szczególnie ciężki: nie wstaje już z łóżka o własnych siłach. Nawet przewrócenie się zboku na bok (konieczne dla uniknięcia zapalenia płuc) - stanowi bolesny problem dla Niego, jak też coraz trudniejszy dla „,sanitariuszki Kali” władającej zaledwie jedną ręką (na cholerny „bersitis” - czy jak to się tutaj nazywa — zastrzyki CORDISONU do ramienia przestały pomagać). Kiwający się zaś kikut na temblaku więcej przeszkadza, niż pomaga. Proszę więc naszego Heniulka, aby zawiesił mi na szyji ukochane łapki, a drugą ręką podtrzymuję łamiący się krzyż — ostrożnie, ostrożnie, no bo każda zmiana pozycji to — powstrzymywany wykrzyk bólu obopólnego...

\footnotetext{
${ }^{4}$ Jean de La Fontaine (1621-1696), znany francuski bajkopisarz doby klasycyzmu, autor ok. 250 bajek; być może chodzi tu o bajkę Młynarz, syn jego i osioł.
} 
Spełniam moją rolę jak mogę najlepiej (co nie znaczy, że dobrze). Ale owe wszelkie czynności zajmują mi dosłownie 20 godzin na dobę. Pozostałe 4 godziny śpisz na stojąco, chodząco, leżąco, oraz w różnych przypadkowych pozycjach nienadających się dla wykończenia raz zaczętego listu. I ten także tkwi w maszynie od paru tygodni. Przebaczcie więc plątaninę myśli, mowy i uczynku korespondencyjnego.

Tyle o nas. Resztę detali związanych z aktualnym „stanem rzeczy” możecie sobie dośpiewać „na pridumku” (czego, dla waszego samopoczucia, raczej nie radzę). Macie wystarczająco własnych kłopotów: metrykalno-fizyczno-psychicznych (pieska Wam tylko zazdroszczę...), aby własnymi pojękiwaniami omraczać życie — ostatnich i najbliższych sercu pamiętających MOHIKANÒW.

Jeśli chodzi o mnie, to operację katarakty na jednym oku tak mi spaskudzili (podobno był to jeden wypadek na tysiąc), że z drugim boję się już ryzykować aby kompletnie nie oślepnąć. O malowaniu więc mofffy nie ma, tak ze względu na brak czasu, jak też ów cholerny wzrok. Nawet niespane noce trudno mi urozmaicić sobie jakąś „rozweselającą” literaturą na dłuższą metę. Wszystko to nie ważne, póki jesteśmy razem.

Teraz a propos Twojej fotografii, wielebny Proboszczu parafii św. Svaneke ${ }^{5}$. Jak pragnę kichnąć — to był szok, z którego jeszcze nie oprzytomniałam! Myśląc wstecz, wyobrażam sobie, że gdyby mnie ktoś obserwował podczas otwierania listu — doznałby wrażenia, że moja reakcja była na poziomie — dobrze odegranej roli aktorki filmowej na próbie generalnej przed wymagającym reżyserem. Mianowicie: otwieram kopertę, z której wypada ów portret. Ułamek sekundy i - kładę go frontem na moje biurko-raizbret (czyli: chyłkiem — tyłkiem do góry). Coś mi przelatuje przez łepek co trudno by określić inaczej, jak: „nie — to niemożliwe”... Znowu kilka sekund zbierania myśli i — powolutku — odwracam fotografię tak, jak to czynią pokerowi gracze dobierając ostatnią kartę do trzech asów. No i - nie ma 4-tego asa, ale jest: Dżoker! ${ }^{6}$ Nasz kochany Jorgen-Dżoker!!! Przebrał się za proboszcza lub pastora (tylko brakuje białego rąbka przy kołnierzu); włoski pochlapał kwaśną śmietaną i... pozuje na „wielebnego". Cóż za oblicze! Wybaczający wszystko dobry uśmiech; kilka zmarszczek przy oczach, nieodzownych dla poczucia humorku; wielka serdeczność w spojrzeniu Człowieka, który sam przeszedł dużo i wiele rozumie i przebaczy. Nic — tylko zamówić się do Niego na „ostatnią spowiedź, błogosławieństwo i krzyżyk na drogę”.

Poszłam więc do sypialni, żeby odczytać Henryśkowi Twój list i pokazać fotografię. Jego reakcja na nią była podobna do mojej: wzruszony - najserdeczniejsza (prosił, żeby Go podnieść nieco na poduszce, aby przyjrzeć się dokładniej przez szkło powiększające, bez którego nie może już widzieć dokładnie.

Nasza, atoli, obopólna złość obróciła się przeciwko prasowym pismakom, którzy musieli czekać 40-letniej rocznicy, aby „odkryć” i uhonorować swego (i naszego) Bohatera. Niech im Wasz kochany piesek mordy nie liże. Pshaw!!!

\footnotetext{
${ }^{5}$ Wzmianka o Jørgenie (po polsku Jerzy) jako „wielebnym”, jest nawiązaniem do portretu art. malarza Jana Zamoyskiego (1901-1986), którego autorka namalowała w 1980/1981 r. (?) jako Meksykanina w czasie jego pobytu w USA i ofiarowała go Mogensenom. Portret pocztą dyplomatyczną dotarł do Danii. Obecnie w posiadaniu autora. Po otrzymaniu fotografii Jørgena, artystka w swej wyobraźni widziała go jako duchownego. Jego wygląd zewnętrzny, wiedza historyczna, znajomość literatury polskiej oraz teologii katolickiej (formalnie nie był katolikiem) powodowała takie skojarzenia. Do realizacji pomysłu, ze względów oczywistych, nie doszło.

${ }^{6}$ Dżoker, dodatkowa karta w talii, zwykle z wizerunkiem błazna, zastępująca w niektórych grach inną kartę.
} 
Pod wpływem tej fotografii, którejś z moich „białych nocy” wykukałam poemacik ku Twojej czci, WIELKI PATRYJOTO obojga NARODÒW, a na złość lewomańkutowym reporterom tychże "środków masowego przekazu". Wierszyk staroświecki, bo... do rymu. Albo go dołączę do listu, albo nie, gdyż strasznie naiwny. Aliści wprost od krowy, czyli ze szczerego serca. Musiała bym go zresztą przepisać o ile sama wyczytam łóżkowe bazgroty pisane dosłownie na podniesionych kolanach.

A teraz poważnie: pojęcia nie masz, jak ta fotografia „wstrząsnęła moją znękaną duszą malarską" odstawioną od cycka zaschłej palety i zakurzonych sztalug. Od blisko dwóch lat nie ruszyłam pędzla (tak ze względu na brak czasu, jak też kłopoty wzrokowe). Zresztą — poza Henryśkiem — wszystko przestało mnie już obchodzić. Tym niemniej, od czasu do czasu, łapią mnie jeszcze te ciągoty; tym ostrzejsze, że beznadziejne. I właśnie owa fotografia miała ten skutek — przecież to portret jak ulany, pod każdym względem (tylko Twoją prawą rękę zmienić z kieliszka na zahaczony palec o łańcuszek od krzyża i dodać biały rąbek pod kołnierzem i — poemat aż się prosi!

Jaka szkoda, że nie miałeś siwych włosów kiedy mieszkaliśmy tak blisko i mógłbyś mi pozować przez godzinkę... Z samej fotografii, to (poza wymienionymi powyżej trudnościami) — jakoś nie wiem czy bym wydoliła??? Ale, podkręciłeś mnie ją, Jorgenie, jak jasny gwint.

Dużo dziękuję a jeszcze bardziej żałuję. Muszę bowiem pogodzić się z faktem, że my już nigdy nie opuścimy naszych pieleszy na własnych nóżętach a Wy nie dacie rady objawić się nam „par-avion”, aby pozować Kali do jej wymarzonego „arcydzieła” którejś-tam-muzy...

A propos wszelkich muz: będziemy oczekiwać nieciepliwie obiecanej fotografii naszej Muzuchny (chociaż w wykonaniu kretyńskich mańkutów-pismaków). Martwimy się ogromnie Jej komplikacjami po-operacyjnymi. Daj Boziu, żeby była zdrowa dla siebie, Ciebie i - dla nas!!!

Kończę ten list-tasiemiec, pisany jak "powieść w odcinkach", po kilka linii za jednym zasiadem, czyli: „do jutra — dalszy ciąg nastąpi”. Wybaczcie więc: styl, powtórki, błędy ortograficzne, etc.

Kochamy Was co nie miara teraz i zawsze i na wieki wieków -

Może jeszcze zmieszczę tego Żołądkowego ,solitera”. Oto on:

Henryk i Kali

POEMAT

KU CZCI NIEZŁOMNEGO DYPLOMATY

A POTĘPIENIU MAŃKUTÒW-PISMAKÒW

OBU NADBAŁTYCKICH KRAIN

(Można nucić na melodię:

Niech nam gwiazda pomyślności nigdy nieeee zagaśnie — bis, a kto zdrowia nie wypije... etc.)

Niechże Cię kaczuszka kopnie

Jorgenie — Dżokerze!

Mogłeś nabrać na to Prasę,

lecz nas nie nabierzesz!

Ni siwizna, ni ,sutanna”

niczego nie zmieni - 
byłeś, jesteś, będziesz młodym do późnej jesieni.

Z serca bowiem pozostaniesz, Drogi Dyplomato, tak wiosenny, jak pierwiosnek rozkwitnięty w lato.

Na KOMUNY zaś wichury mrożące do kości wypniesz się im chyłkiem-tyłkiem: „z czym, chamy, do gości?”

Oto powód i przyczyna, do jasnej cholery:

pocałujcie mnie - przepraszam we... cztery litery!

Dziś możecie popisywać się swoją PRZESZŁOŚCIĄ lecz dla wielu wasze szpalty stają w gardle ością...

Kolorowa fotografia też nic nie odnowi:

wy płyniecie z ,nowym prądem”, ja - przeciw prądowi.

Wasze zasmarkane hasła kwilicie dla zysku wiedząc, że się nie ośmieli nikt wam dać po pysku.

Kwilicie sobie ile wlezie, wyłącznie dla „mody”. Wasze trele już są stare jam jest DUCHEM młody!

I tak można by godzinami, gdybym nie liczyła się z Waszą cierpliwością — Waszą cierpliwością, gdyż to wszystko co czerwone (albo różowe) przepawa nas złością.

I dlatego, Najukochańszy, nie jestem wzruszona, że na ,szpaltach" ukazałeś, się: Ty i Twa Żona... 
Mogłyby, fircyki, przypomnieć sobie CHWAŁĘ własnych wyjątków nieco wcześniej. Czego i Henrykowi życzę...

4.

[San Francisco] 20-21-22-go stycznia 1987

Nasi bardzo a bardzo kochani OSTATNI MOHIKANIE !!!

Dzięki za list świąteczny i tak bardzo serdeczną pamięć o nas, mimo ciszy z nad Zatoki świętego Franciszka (ciszka, ciszka). Po raz pierwszy od ćwierć wieku nie zdołałam zorganizować Bożonarodzeniowych passpartutów ${ }^{7} \mathrm{z}$ odbitkami mojej radosnej twórczości, ani nawet wysłać zwykłych kartek z życzeniami. Do nikogo.

Nie mogłam. Darujcie. Tak ze względu na kompletny brak czasu, jak i trudność sklecenia „cheerful \& joyous words” for Marry Christmas.

Aby skończyć z tym tematem i nie rozklejać ani Was, ani siebie - powiem w wielkim skrócie, stosując kilka szczególnie pasujących do okoliczności tytułów ongisiejszych bestellerów: niespane Noce i Dnie z halniakowym Wiatrem w Oczy, plus przypomnienie, że nie wszystkie Drzewa Umierając Stojąc ${ }^{8}$ i nie wiadomo kto Pierwszy do Raju. W sumie: Na Zachodzie bez Zmian (na lepsze). Będąc zaś, paszportowo, tzw. „dzwonkiem katolika” - chciałabym zapytać naszego kochanego Lolka z Watykanu: po jasną anielkę każą nam się modlić aby dobra Bozia „zachowała nas od Nagłej i Niespodziewanej..."??? Przecież to kompletny absurd! Podobnie, jak wprowadzenie do katolickiej Mszy miejscowych języków, zamiast łaciny (opinia mojej milutkiej murzynki z Haiti: niech mówią co chcą, ale ja myślę, że to jakoś... nie ładnie. Dotychczas, gdziekolwiek człowieka rzucił los — wiedziało się, że w kościele to jak w domu wspólny język") Ja też tak uważam; chociaż dla modlitwy nie jest mi kościół potrzebny. Wolę las na górze Davidsona9; albo chwilkę skupienia przy zmywaniu naczyń; praniu; czy podlewaniu naszego patio ${ }^{10}$. Zresztą - to nie wyłączne głupstwo dyplomatyczne, do którego zmusili Lolka ${ }^{11}$ „panowie w szkarłatach” — Szkoda gadać.

Cieszę się dla Was z kontaktu z łabędziami ${ }^{12}$, wróblami, pieseńkiem, oraz — odwiedzinami, from time to time, „ludzmi z czasów nieodwołalnie minionej epoki”, jak

\footnotetext{
${ }^{7}$ Passpartut, chodzi o fotografie-miniatury prac malarskich oprawione w pase-partout, które artystka wysyłała do przyjaciół każdego roku z życzeniami na Boże Narodzenie wraz z opłatkiem. Dzięki temu, że ich posiadacze ofiarowali je Archiwum Emigracji, posiada ono kolekcję takich miniatur oraz jeden portret siostrzenicy (przed pójściem do zakonu), który otrzymało w darze od autora.

${ }^{8}$ Drzewa umierają stojąc (1949) to najgłośniejsza ze sztuk Alejandro Casony (1900-1965), hiszpańskiego dramatopisarza, przyjaciela Federico Garcii Lorki. Przedstawienie widzieliśmy w Teatrze Rozmaitości w Warszawie, gdzie w roli Babki występowała Mieczysława Ćwiklińska (1879-1972).

${ }^{9}$ Góra Dawidsona (Mount Davidson), najwyższy naturalny punkt w San Francisco, widoczna $\mathrm{z}$ willi Weynerowskich.

${ }^{10}$ Patio, w architekturze hiszpańskiej, portugalskiej i iberoamerykańskiej, wewnętrzny dziedziniec w pałacach, willach i domach, najczęściej wyłożony płytkami.

${ }^{11}$ Lolek z Watykanu, papież Jan Paweł II (pontyfikat 1978-2005).

12 Łabędzie na kamienistym wybrzeżu Bornholmu. Na trasie codziennego spaceru Jørgena Mogensena z psem „Toby” (około $5 \mathrm{~km}$ ) było zawsze kilka łabędzi, o których mówił, że są z Polski i rozmawiał z nimi po polsku; wróble przylatywały regularnie do karmnika w ogrodzie otaczającym willę, a gdy gospodyni lub gospodarz się spóźniał z wysypem karmy, to pukały do okna.
} 
to określiła w miłym liście (i telefonicznie) pani Langerowa (zapomniałam jej imienia). Ze wszystkich Waszych przyjaciół najbardziej lubiliśmy Doktora Sheldon, stanowiącego bez wątpienia rzadki wyjątek potwierdzający ogólną, i smutną, opinię tutejszej etyki lekarskiej. To są, istotnie, rzeczy nie do wiary, o których nie śniło się nam jeszcze za Waszej tutejszej „kadencji”.

Była bym wdzięczna za podanie mi, przy okazji, Jego i Japoneczki adresu (tel.?). Od czasu pogorszenia się choroby Henryśka — nie widujemy właściwie nikogo. Zależało by mi ogromnie na kontakcie chociaż by z JEDNYM uczciwym lekarzem. Możecie być pewni, że nie będę wykorzystywać tej znajomości w sensie „darmowych porad". Ta prośba była by jedynie aktualna, gdyby oni nadal mieszkali w zasięgu obu stron naszej Zatoki; inaczej forget it.

Do Was, Kochani, tęsknimy ogromnie, gdyż jak się rzekło — tamta epoka skończyła się bezpowrotnie i, właściwie wspominam ją trochę tak, jak dawną Warszawę... Tyle, że Wasz domek z zielonym dachem dalej stoi; ale tak jak nasz na Żoliborzu zamieszkały przez obcych. I również Wy jedyni jesteście jeszcze osiągalni na ślicznym adresie, żywcem wyjętym z „Cudownej podróży” Nilsa Holgersona ${ }^{13}$ (którą to książkę zdążyłam sobie sprowadzić z Polski przed jej wyczerpaniem). Ilekroć adresuję do Was kopertę z magicznym słowem VIPPEBAKKEN — natychmiast myślę o tej starej dzikiej gęsi, Akka z Knebnekaise, z której stadem podróżował mały Nils na grzbiecie domowego gęsiora, zwiedzając całą Szwecję, ucząc się sam (jak i młodych czytelników) jej geografii, historii, etc. Iście cudowna podróż i cudowna książka. Akka nawoływała swoje stado w czasie lotu: „gdzie jesteś?? tu jestem! Gdzie jesteś? Tu jestem!” (to samo hasło przetrwało z moją Halinką nieodłączną w czasie szkolnych wagarów parku Frascati na Wiejskiej; jak później, podczas Powstania na Starówce, aż już zamilkła w pierwszych dniach obrony Czerniakowa...)

Chciałabym z całego serca, żeby nasze przyjacielskie stadko nie pogubiło się w odległych przelotach na coraz trudniejsze do osiągnięcia „wyraje” i żebyście odpowiadali na milczące wołanie Waszej starej gęsi, Kali z Knebnekaise : „TU JESTEM”

Kali

Tak marzyłam, Jorgenie, o namalowaniu (z pamięci i z fotografii) Twego konterfektu (,Trylogia”) a la... „proboszcz z poczuciem humoru” (może z ptaszkiem na ramieniu, czy patrzącego na ptaszki za oknem -). A tymczasem do łazienki doskakuję w ostatniej chwili; list do Was uskuteczniam nocami, po kilkanaście minut za jednem zasiadem; odżywiam się chlebem francuskim z serem o przeróżnych porach; zasypiam na 23 godzinki, gdzieś nad ranem, między 7 a 10-tą. Reszta czasu, to: „Czyhanie na Boga” przy moim kompletnie bezwładnym Henryśku. Ale z Bogiem — to tak niekiedy, jak z biskupem (przepraszam prałatów i Pana Boga).

No, to już koniec. Darujcie ten rozstrzelony list i odpowiedźcie mi zawsze, chociaż myślami — „TU JESTEM”. Dziękuję.

${ }^{13}$ S. Lagerlöf, Nils Holgerssons underbara resa genom Sverige, Stockholm 1906, 1907. W przekł. polskim: Cudowna podróż, Warszawa, 1910, 1911; wyd. 2: Warszawa 1955. Nils Holgersson — postać z powieści. 
Najukochańsi — najdalej najbliżsi!

Dzięki stokrotnie za Wasz serdeczny list, pełen wyczucia i zrozumienia dla naszej nowo zaistniałej sytuacji. I ja także wierzę, Jorgenie, w Twoją moc „uczucia, która samym przyłożeniem ręki, przyniosłaby Henrysiowi ulgę", taj, jak to czynisz z chorymi czy skaleczonymi zwierzątkami. W każdym razie, od odczytania Mu Twego listu — nie ma już pogorszenia. A to zawsze ... coś.

Na temat naszych problemów nie chcę rozpisywać się więcej. Natomiast: niepokoimy się bardzo tym, co piszesz o Muzce. Jak można, przy dzisiejszym stanie medycyny, tak spaskudzić najprostszą ze wszystkich operacji? Daj nam, proszę znać — chociaż w kilku słowach, jak się obecnie czuje i czy groza ponownej operacji nie wisi już nad Wami?

A Ty sam, siwy gołąbeczku, uważaj na siebie — : tak dla Muzuchny, jak i dla Waszych wiernych przyjaciół sanfanciszkańskich z młodociano — odległej epoki, którą wspominamy z rozczuleniem.

Ściskamy Was Obojga z całego serca - pocałuj od nas Waszego psiaczka, ptaszki, łabędzie i wszelkie Twoje podopieczne zwierzątka. Cieszę się, że ta ochydna zima europejska już chyba „popuściła”. Nie zamęczaj się, Jorgenie kochany, pracą w ogrodzie — Kochamy mocno

Kali i Henryś

6.

[San Francisco] 7-go sierpnia 1989

Hi — bardzo a bardzo Kochani!

Dzięki za list i Waszą serdeczną pamięć. Zwlekałam z odpowiedzią, bo coś mi się znowu popsuło z zadnią koń-i-czynką, więc nie chciałam pisać w nastroju „chandry unyńskiej" (o ile pamiętasz ten wiersz Tuwima?).

Jeszcze na wczesną wiosnę, w szpitalu, tak wierzyłam w dobry rezultat owej ponownej operacji, że pochopnie zaklepałam z bliską mi Stefanią wspólny wypad do Kraju na 50-cio-lecie i naoczny sprawdzian lawinowo pędzących faktów historycznych.

Już były wizy PRL-owskie w paszportach i miejscówki samolotowe na 23-go sierpnia. Już sobie marzyłam, że w drodze powrotnej, wpadnę do Was chociaż na parę dni intensywnej rozmowy i szybkiego szkicu Jorgenowego oblicza, z którego w domu uskuteczniłabym może Jego malarską podobiznę a la ,proboszcza parafii Vippebakke" ${ }^{, 14}$ do czego natchnęła mnie ta Twoja fotografia w czarnym wdzianku.

Aliści i apiat' - znowu G — jak Gienia Wiechowska. Nie dam rady. Jechać do Polski, czy gdziekolwiek, i nie móc przeczłapać jednego bloku bez dłuższego odsapu — to już mówiąc po krajowemu, nie „małe piwko”, a raczej ... duży kielich goryczy;

14 Vippebakke (w wolnym thumaczeniu — lagodne wejście na wzgórze), nazwa ulicy w miasteczku Svaneke, przy której Mogensenowie wybudowali dla siebie willę (1970) i gdzie zamieszkali po przejściu na emeryturę. Stąd było najbliżej do Polski. 
czyli: zwyczajny absurd i sportowo-ambicyjny „policzek” dla mnie, a dla bardzo opiekuńczej Stefki spore obciążenie.

Wobec powyższego: jeszcze jedna rezygnacja i — byle do „następnej wiosny” (wielokropki i znaki zapytania — do rozmieszczenia...???).

Jeśli chodzi o ten projektowany przed rokiem ,piękny album” moich malarskich wyczynów, obejmujących pełne 40-sto-lecie i wszystkie kolejne style — to poświęciłam mu kupę czasu, starań i forsy. Niestety, wydanie da się sfinansować (jak pouczają liczne bezskuteczne próby) jedynie ze sprzedaży naszego domku, co jest wyraźnie zastrzeżone osobnym paragrafem mego, pardon, TESTAMENTU. Oczywiście ogromnie żałuję, że go nie zobaczę — ani ja, ani Henryś, któremu jest w przedmowie poświęcony (fotografie, kolorowe negatywy, kurikulum, spis wystaw, oraz cała masa przychylnych mi tekstów z Twoim włącznie) jest najdokładniej posegregowana i zapięta na ostatni guzik - w osobnej skrzyni sypialnej w oczekiwaniu ewentualnego „odkrywcy” popartego moją „ostatnią wolą”. Nie będzie więc miał z tym dużo kłopotu. Pshaw.

Co do Polskiego Muzeum w Rapperswilu ${ }^{15}$ to, jak Ci już zdałam relację dokładną przed chyba rokiem, czy nawet dwoma: wedle tego testamentu — plus dołączona umowa prawna podpisana przez obie strony (świadkowie, pieczęcie i cały ten oficjalny „trimming”) - Muzeum otrzymuje wszystkie pozostałe po mnie obrazy, bez prawa, atoli, ich sprzedaży ( $\mathrm{z}$ minimalnym wyjątkiem \$30-tu tysięcy na pokrycie kosztów transportu. Czyli, wedle ostatnio uzyskanych cen -2 lub 3 obrazy). Zobowiązali się natomiast do stałego udostępniania „wglądu publiczności” zwiedzającej Muzeum co najmniej kilkunastu na stałym display. Zgodziłam się również na ew. wypożyczanie tego-czy-owego, pod odpowiednią gwarancją i ubezpieczeniem, innym szwajcarskim muzeom, lub galeriom. That's all.

Zważywszy drobny fakt, że Jan Nowak (Zdzisław Jeziorański ${ }^{16}$ — ten od paru dziesiątków lat dyrektor Radia Wolna Europa, a obecnie spora szyszka w Waszyngtonie) przekazał Rappersvil całą swoją kolekcję (???), opłacając za jej utrzymanie sporo forsy jeszcze „za życia” — nie myślę, abym załatwiła to specjalnie głupio. Ostatecznie, z czym durnej Kali do bestsellerowego „Kuriera z Warszawy” i w ogóle „MSZ-owskiej pozycji” Nowaka itp Brzezińskich ${ }^{17}$ ?

Odpowiedź na kolejne pytanie: Pana Kruszewskiego ${ }^{18}$ nie znam (przynajmniej nie pamiętam, czy go kiedykolwiek poznałam). Jeżeli jest z tzw. „emigracji londyńskiej” to i tak miło z jego strony, że w ogóle coś o mnie napomknął. Tamtejsi bowiem ziomkowie, z niewiadomych przyczyn, prowadzą politykę raczej anty-amerykańską. Typowe rozgrywki rodackie. Ongisiejszy artykuł o Kali, znanego Torontańskiego pisarza-poety Wacława Iwaniuka ${ }^{19}$ (drukowanego nawet w Polsce w ,,drugim obiegu”), został odrzucony przez „Wiadomości Literackie”, jako ... penegiryk??

Mam oczywiście czas. Ale, w obecnym nastroju nie mam definitywnie energii na wypisywanie, po raz już nie wiem który, czegokolwiek na własny i Henrysiowy temat.

15 Rapperswil, Muzeum założone w 1870 r. przez Władysława hr. Broël-Platera, przy znacznym wsparciu szwajcarskich przyjaciół skupionych wokół pisarza Gotfryda Kellera. Nieśli oni pomoc powstańcom styczniowym i dzielnie wspierali starania emigrantów w tworzeniu ośrodka naszej kultury i historii.

${ }_{17}^{16}$ Jan Nowak Jeziorański (1914-2005), dyrektor Polskiej Sekcji Radia Wolna Europa.

${ }^{17}$ Zbigniew Brzeziński (1928-2017), doradca ds. bezpieczeństwa prezydenta USA J. Cartera w latach $1977-1981$.

${ }^{18}$ Eugeniusz S. Kruszewski, autor artykułu.

${ }^{19}$ Wacław Iwaniuk (1912-2001), poeta, pisarz, krytyk literacki. 
Jeśli więc uznasz to za wskazane i podasz mi adres pana Kruszewskiego, to prześlę $\mathrm{Mu}$ bezpośrednio xeroxy całego tekstowego zestawu przygotowanego dla Albumu. Będzie miał tam wszelkie dane na mój (nasz) temat życiorysowo-malarski (z wyjątkiem nazwiska panieńskiego mojej Matki, o które pytasz, i paru innych, w moim pojęciu nieistotnych, szczegółów natury prywatnej. Jeśli chcesz wiedzieć, to Mamuśka była z domu Czarnocka. A do Gordziałkowskich nie przyznaję się chętnie - zakute endeki i snoby...).

Poza Tobą jest w tym zestawie szereg znanych i cenionych, po obu stronach Oceanów, nazwisk, spis wystaw, kolektorów, etc. I to powinno wystarczyć. Wątpię jednak, czy z wymienionych powyżej względów, jakiekolwiek londyńskie pismo będzie skłonne uwzględnić i mój znikomy wkład do emigracyjnej niwy kulturalnej.

Mówię o tym bez cienia goryczy, jako że - już teraz, po odejściu Henryśka, wszystko to razem przestało mnie kompletnie obchodzić.

Na tym kończę tę niemożliwie rozwlekłą epistołkę - więc do widzenia, Kochami, bądźcie tylko zdrowi!

Ściskam Was najserdeczniej

Kali

W tych, jak by nie było, historycznych miesiącach (nie tylko dla Polski), ogromnie żałuję, że nie macie dostępu do paryskiej „Kultury”. Żadne inne pismo - ani krajowe, ani zagraniczne - nie daje tak 4-ro wymiarowego przekroju lawinowych przemian, faktów, społecznych nastrojów, oraz bezstronnej oceny.

7.

[San Francisco] 24 wrzesień 1990

Moi bardzo a bardzo Kochani!

Już nie będę odkładać odpowiedzi na Twój - jakże dobry, serdeczny i bliski — list, na który nie zasłużyłam swoim tak długim milczeniem. Już wolę wystukać byle-jako sklecony dowód nieustającej pamięci o Was i wielkiej tęsknoty, niż odkładać to do lepszego samopoczucia fizyczno-psychicznego, na który trudno liczyć w zaistniałej sytuacji. Darujcie, że chociaż w wielkim skrócie, muszę jakoś streścić powody mego zamilknięcia od tylu lat. To nie żadna „skarga”, czy „ubolewanie” na zły los. Jedynie częściowa próba samo-usprawiedliwienia przed wyłącznie najbliższymi: przed odejściem Henryśka, kiedy zaczęły się te skrzepy w arteriach, nie mogłam sobie pozwolić na dłuższy pobyt w szpitalu. Załatwili to jakoś „tymczasowo” — over night, dwa dni, najwyżej tydzień. Nic nie pomogło. Przed dwoma laty, kiedy już nie miałam do kogo wracać do domu, a groziła gangrena - zaczęły się te krajanki-rąbanki lewej nogi; po parę tygodni w szpitalu, a parę miesięcy kusztykania domowego. Ciągle jeszcze wierzyłam, że to coś pomoże. Aliści — „G jak Gienia” wedle ś.p. Drogiego Wiecha ${ }^{20}$, kolejny skrzep umiejscowił się w aorcie przy sercu. Tym razem wedle szczerych a durnych rad tych-i-owych (pamiętasz Bajki de La Fontaina?) zdecydowałam się na innego chirurga i szpital uniwersytecki. No - i to wykończyło mnie ostatecznie do dnia dzisiejeszego. Rozpruli mnie od góry do dołu (dalej* już nie mogli ze względów anato-

\footnotetext{
${ }^{20}$ Stefan Wiechecki, pseud. Wiech (1896-1979), pisarz Warszawy, felietonista warszaw-
} skich dzienników. 
micznych), jak Thangsgiving ${ }^{21}$ indyka, które to święto właśnie celebrowano hucznie, więc ichniejsze nursy nie reagowały na dzwonki swoich podopiecznych. Byłam przywiązana ze wszystkich stron niezliczonymi sznurkami-rurkami (nos, gardło, ręce, nogi, etc.); ciemny pokój; jakieś multikolorowe widziadła i — niesamowity ból (jak się okazało następnego dnia - materac był z ,początku wyrobów plastikowych”; twardy, jak siodło i wyfryzowany na kształt... pół pomarańczy, zmieniających swój deseń w górę i w dół — możecie sobie wyobrazić?)

Nie wiem, jak dobry (czy zły) był mój starszawy chirurg? Ale — taki szpital mogę sobie jedynie wyobrazić w jakimś obecnym Piotrkowie, czy Wyszkowie. Nigdy w Ameryce. Do dnia dzisiejszego budzą mnie w nocy owe makabryczne wspomnienia tych paru tygodni spędzonych pod „opieką”... beczelnych nurs i, może jeszcze gorszych, szczeniaków, dopiero praktykujących lekarzy.

Po powrocie do domu — znowu 10 dni w łóżku (detali ,samotnego cierpienia” nie wymieniam, zważywszy na Wasz - i mój własny wstręt do tego tematu). Łatwo nie było. No, i nagle, ,po-operacyjna komplikacja” czegoś-tam przeoczonego. Więc znowu: szpital (już tym razem mój dawny). Powrót do domu. Łóżko. Sama. Szfit. Książki były za ciężkie do utrzymania. Jeść (ani nawet wspomnienie o jedzeniu, znieść nie mogłam), chociaż matka „Niańki Pryszcz” odwiedzała mnie bardzo poczciwie. Anielka. Ta cała zabawa trwała od końca listopada poprzez grudzień. W styczniu obecnego roku, zanim jeszcze mogłam wstać po Uniwersyteckim katakliźmie - nagły, potworny ból - znowu w lewej nodze. Na półprzytomną Anielka odwiozła mnie do dawnego szpitala: a piat' groźba gangreny. A piat' operacja i parę tygodni szpitala. A piat' tygodnie domowych pieleszy. I znowu Wiech, ze swoją Gienią.

Miało być w ,skrócie”. Wyszło za długo. Przepraszam.

W rezultacie i w rezul-mamie: po domu, przy lepszych dniach, funkcjonuję jakotako w godzinach późno-popołudniowych (noce są nie spane). Przy bardzo nielicznych „gościach” potrafię nawet zachować... „twarz jednakową — ciszę błękitu” oraz markować podpieranie się ścianami, krzesłami itp. podręcznymi sprzętami.

Aliści, każdy z tych — na szczęście nielicznych — performanców opłacam co najmniej dwudniowym leżeniem w łóżku, buzią do sufitu i — wspomnieniami dawnych, dobrych czasów zamierzchłej sportowności. A niech to kaczka kopnie!

$Z$ tych też względów trzymam (most of the time) telefon wyłączony: z prawdziwych PRZYJACIOŁ miejscowych mam tylko już jedną (nie znacie jej). Niestety, mieszka na Marinie, czyli daleko, ale odwiedza mnie dosyć często. A na reszcie pół znajomków nie zależy mi. Nie mam już na nich ani sił, ani energii, ani ochoty.

Przed nieuniknioną (a chyba usprawiedliwioną depresją - co za ohydne słowo!!!) bronię się jak mogę. Nie jest łatwo (przypominam sobie naszego biednego Piotrowszczaka). Ale, żeby ten cholerny Los, zabrawszy mi wszystkich NAJBLIŻSZYCH, z Wami włącznie, pozbawił mnie jeszcze możliwości nie tylko już malowania, ale chociażby możliwości pisania i spacerów po naszej górze, to — widzi mi się za dużą karą za wszelakie, pamiętne czy nie, grzechy.

Wyobraź sobie Jorgenie - Ty, który kochasz „chodzenie w zielone” — żebyś nie mógł przejść z jednej strony ulicy na drugą bez podpierania się o krzaki? Żebyś nie miał prawa do chociażby psiaczka, żeby z nim porozmawiać? Żeby listowny kontakt z najbliższymi trzeba było opłacać każdorazowo... paru dni leżenia za każdą nabazgra-

${ }^{21}$ Thanksgiving Day, oficjalne święto narodowe obchodzone w USA od 1863 r. w czwarty czwartek listopada z pieczonym indykiem i tortem z korbasem. 
ną, czy wystukaną stronniczkę??? A — niech to cholera trzaśnie. I, im prędzej, tym lepiej.

Teraz widzisz, Kochany, dlaczego nie piszę. Takie zwrotki-stokrotki z czkawkowym refrenem - to nie moja melodia. To raczej jakiś depresyjny katar, którego nie chcę, za Boga, nikomu przekazywać.

Do widzenia, moi bardzo Kochani, zawsze Wasza Kali

8.

[Tekst pisany na odwrocie reprodukcji obrazu Bonne a Tout Faire]

16-go maja [19]91

Kochani - zawsze i bardzo a bardzo,

nie gniewajcie się za tak długie milczenie, nie potrafię (nie chcę, nie umiem, nie warto -) tłomaczyć się co - i jak i dlaczego, aby dzielić się z kimkolwiek owymi problemami. Obiecuję napisać dłużej na wiele bardziej interesujących tematów, jak tylko będę w nieco lepszej formie.

Tymczasem jedynie te kilka słów, żebyście wiedzieli, że jestem i myślę o Was i do Was najserdeczniej z wielką tęsknotą.

Ściskam z całego serca

Wasza Kali

\section{9.}

San Francisco, 2-go czerwca 1991

Moi baardzo Ostatni Mohikanie,

W ostatniej kartce napisałam (o ile sobie przypominam), że jesteście już prawie ostatni z najbliższych nam Przyjaciół. Omyłka w druku. Jeśli bowiem chodzi o Prawdziwych Przyjaciół przez duże „P” — to takowych, poza Wami, już nie posiadam ani na lekarstwo. Jest jeszcze ten i ów, tu czy tam, serdecznie mi oddanych, ale... to już nie to samo. Wyjątek stanowi mój cioteczny szwagier, prof. Kazik Czereyski ${ }^{22}$ z Milanówka, dla którego, po śmierci Wandki, stałam się (wzajemnie) jedynym łącznikiem Rodziny Szopenowskiej (on nazwy ulicy naszej wspólnej młodości).

Ma swoje dzieci i wnuki, ale jak mówi, ,to już nie to samo”. Do mojej rodziny był, i pozostał, bardziej przywiązany niż do swojej. Dopiero stosunkowo niedawno zdałam sobie sprawę z istotnej wyjątkowości „KLANU CZARNOCKICH”23 z pokolenia na-

${ }^{22}$ Kazimierz Zaremba Czereyski (1909-1996), inżynier leśnik (1934), profesor nauk leśnych. W czasie II wojny światowej był w obozach w Kozielsku i Griazowcu. Po zawarciu układu Sikorski-Majski wstąpił do Armii Polskiej gen. Andersa, z którą przeszedł szlak bojowy przez Iran, Palestynę, Włochy. Po wojnie trafił do Anglii, skąd w 1947 wrócił do Polski. W tym samym roku został zatrudniony w Instytucie Badawczym Leśnictwa, gdzie pracował do emerytury. Autor ok. 300 publikacji (w tym wielu opracowań popularnych) na temat leśnictwa; zob.: J. Stajniak, Profesor Kazimierz Zaremba-Czereyski - wspomnienie, Sylwan 1996 t. 140 z. 7, s. $103-105$.

${ }^{23}$ Prawdopodobnie chodzi m.in. o doc. dr. med. Wilhelma Czesława Czarnockiego, zam. ul. Rejtana 3; zob.: Czy wiesz kto to jest?, red. S. Łoza, Warszawa, 1938. 
szych Matek, Ciotek, Wujów, etc., w przeciwieństwie do zakutych snobów i endeków Gordziałkowskich.

Również, dopiero teraz, zrozumiałam powody licznych wizyt „przy zamkniętych drzwiach" przeróżnych świecznikowych eminencji (z Piłsudskim włącznie), zjawiających się w decydujących politycznie momentach na Szopena, Rejtana, czy w Puławach (tamże byłam raz świadkiem, w bardzo wczesnym dzieciństwie, jak Ciotka Jadwiga, „mówiąca prawdę w oczy”, dosłownie wyrzuciła ówczesnego ministra Juliusza Poniatowskiego $^{24}$ za drzwi: ,jak się zastanowisz nad konsekwencjami swoich obecnych poczynań - to wówczas porozmawiamy" - tyle zdołałam podsłuchać.

A propos mówienia „prawdy w oczy”. Oczywiście, jak wszyscy, przepadałam za Tuwimem (ówczesnym), Boyem ${ }^{25}$, Kaziem Wierzyńskim i Hemarem. Otóż Hemar powiedział kiedyś: „nie cierpię ludzi mówiących prawdę w oczy”. Bo, rzeczywiście. Ci ludzie przeważnie mówią tylko przykrą prawdę, pomijając cechy pozytywne. Moja rodzina należała i pod tym względem do nielicznych wyjątków: mówiła „w oczy” zarówno prawdę miłą, jak też miała cywilną odwagę wypowiedzi krytykujących, bez względu na wyższą, czy niższą pozycję rozmówcy, czy też uczuciową do nich sympatię.

8-go czerwca

Znowu to samo: ilekroć zacznę któryś z prywatnych listów -natychmiast nadlatuje konieczność wystukiwania na maszynie jakowychś oficjalnych papiórków, których ostatnio mam powyżej uszu, oraz fizyczno-psychicznej wytrzymałości (sprawy, za przeproszeniem testamentalne itp. obrzydlistwa). Zamiast więc wrzucania do kosza zaczętych epistołek i zaczynania apiat' nowego listu — postanowiłam wykręcać go z maszyny i, przy pierwszej okazji, kontynuować rozmowę z Wami ala „powieść w odcinkach".

Mówisz, Kochany, o „galopującym niedołęstwie starczym”??? Wypluj ten dowcip przez lewe ramię (byle nie pod wiatr) i przeżegnaj się trzy razy. Jesteś maluczko starszy ode mnie, a, mimo swej serdecznej ,polskości”, za którą kochamy Cię dodatkowo, stanowisz fizycznie okaz wspaniałego SKANDYNAWA, dla którego setka wiosen (bez względu na pogodę) - to szczeniak. Masz więc przed sobą jeszcze kupę lat z okładem. Drobne i irytujące niedomogi w wolniejszym chodzeniu z pieskiem, małe zadyszki, brak energii na czytanie, czy radiowo-telewizyjne wysłuchiwanie coraz to idiotyczniejszych wiadomości politycznych ze wszystkich stron świata — to nie są oznaki starości. Po prostu: nie wiek metrykalny daje się nam we znaki, a raczej „tempo postępu” drugiej połowy WIEKU (pisanymi rzymskimi cyframi), którego nie sposób zrozumieć, ani dogonić. A to działa co-cuś ...przygnębiająco. To samo dotyczy, jeśli chodzi o mnie.

10.

[San Francisco] 22-go czerwca

Tym razem blisko dwutygodniowa przerwa na lekarzy, dojazdy do odległego szpitala, przeplatane odsapami w łóżku na płask, nosem do sufitu, z denerwującą lekturą pism

\footnotetext{
${ }^{24}$ Juliusz Poniatowski (1886-1975), legionista Józefa Piłsudskiego, był ministrem rolnictwa i reform rolnych w Gabinetach: Leona Kozłowskiego, 30 VI 1934-1935, M. ZyndramaKościałkowskiego 1935-1936 i F. S. Składkowskiego 1936-30 IX 1939; zob.: Czy wiesz kto to jest?; Od Moraczewskiego do Skladkowskiego. Gabinety Polski odrodzonej 1918-1939, red. J. Faryś, A. Wątor, H. Walczak, Szczecin 2010.

${ }^{25}$ Tadeusz Żeleński-Boy (1874-1941), pisarz, thumacz, krytyk literacki i teatralny.
} 
krajowych. Nie pamiętam, co chciałam napisać w zaczętym zdaniu? Przypuszczam, że właśnie chodziło o absurdalne rozgrywki polityczne pana Wałęsy ${ }^{26}$ \& Co. Zarówno w Belwederze ${ }^{27}$, jak i na wynos zagraniczny. Z prenumeraty TYGODNIKA POWSZECHNEGO $^{28}$ zrezygnowałam (bardzo pogorszył się $\mathrm{z}$ odejściem Stefana Kisielewskiego $^{29}$ i obu Kozłowskich ${ }^{30}$, zastąpionych szpaltami „,watykańskimi” nieleżącymi w granicach moich aktualnych zainteresowań). Zatrzymałam PRZEKRÒJ ${ }^{31}$ (który na odmianę, poprawił się znacznie) — no i, oczywiście z niczym nieporównaną KULTURĘ paryską.

W aktualnościach krajowych orientuję się zatym dość dokładnie, co nie poprawia oczywiście wielkiego niepokoju, połączonego z wzrastającą „chandrą unijską” (Tuwim)... Z tą „,chandrą”, czyli zwykłą po polsku depresją, staram się walczyć jak mogę. Ogromnie brakuje mi miejscowych ludzi Bliskich; jakiegoś psiaka i - możliwości długich spacerów, do których przywykłam od wczesnego dzieciństwa. Z resztą fizycznych trabli dałabym sobie radę samym uporem i wieloletnim już przyzwyczajeniem.

11.

12-go lipca, jeszcze [19]91

Przyjechał ktoś do mnie na kilka dni z Chicago. Miła wizyta i bardzo serdeczna osoba (żona kuzyna Henryśka; oboje szczerze mi oddani). Tyle tylko, że znowu musiałam „odleżeć" ów minimalny wysiłek przyjmowania gości i zmiany dziennej rutyny, co natychmiast odbija się na moim cholernym niedowładztwie zadnich kończyn, jako też pompowaniu i przepychaniu zatkanych arterii.

Już wyszlę ten zlepek listopy, żeby nie czekać sierpnia, albo zmiany roku. Darujcie jego chaotyczność. Może następny uda mi się sklecić nieco przytomniej. Jeśli możecie — piszcie. Tak bardzo zależy mi na utrzymaniu z Wami kontaktu.

Ściskam Was oboje z całego serca

Kali

Co znaczy „sciastyka”, na którą cierpi nasza Muzka? Czy to jakaś odmiana artretyzmu, z którym miała od dawna kłopoty, czy coś innego. Napisz.

${ }^{26}$ Lech Wałęsa (1943-), przywódca „Solidarności”, prezydent RP (1990-1995).

${ }_{28}^{27}$ Belweder, siedziba głowy państwa w Warszawie.

28 „Tygodnik Powszechny”, tygodnik katolicki o tematyce społeczno-kulturalnej, założony przez kardynała Adama Stefana Sapiehę. Pierwszy numer „Tygodnika Powszechnego” ukazał się z datą 24 marca 1945 r. Komitet redakcyjny składał się początkowo z czterech osób: ks. Jana Piwowarczyka, Jerzego Turowicza, Konstantego Turowskiego i Marii Czapskiej.

${ }^{29}$ Stefan Kisielewski (1911-1991), pisarz, kompozytor, krytyk.

${ }^{30}$ Krzysztof Kozłowski (1931-2013), filozof, dziennikarz, polityk. Maciej Kozłowski (1943-), historyk, publicysta, dyplomata.

31 „Przekrój”, tygodnik założony w 1945 przez Mariana Eilego, który był redaktorem naczelnym pisma przez 24 lata. Pierwszy numer ukazał się 15 kwietnia 1945. W połowie lat 70. pismo osiągnęło rekordowy nakład — ponad 700 tys. egzemplarzy. 
12.

[San Francisco] 12-go grudnia 1994

Jorgenie, śliczna Muzko - bardzo i prawdziwie głęboko Kochani!

Właśnie w tym bieda. Bo niby jak usprawiedliwić, przy takim uczuciu, wielomiesięczną seperację milczenia — i to do Najbliższych, jacy mi jeszcze zostali. Tu, tam, czy gdziekolwiek. Owa trudność bowiem podtrzymania kontaktu par-avion jest tylko częściowo związana z niekończącymi się operacjami itp. trablami natury metrykalnofizycznej (Oczywiście, i w tym nie pomaga odziedziczona po przodkach istna alergia wszelkich wzmianek na temat "szwankującego zdrowia"). Ale nie w tym się rzecz macała...

Jorgenie kochany - Ty, który tyle przeszedłeś i tyle umiesz zrozumieć, tak u ludzi, jak u zwierzątek, - może dasz radę odcyfrować i to, czego ja sama nie kapuję, ani nie potrafię logicznie wytłomaczyć. Tyle tylko, że: od 26-go kwietnia 88-go „B.C.” (czyli: before odejście Henryśka), bo tak mi się teraz w pamięci układa - moim niejako drugim, po malarstwie, powołaniem było... domorosłe pisarstwo. Zawsze sobie miałam w zanadrzu owo, niespełnione słowami, "insurance", że jeśli, z takich czy innych powodów nie mogłabym malować — to znajdę wówczas czas na, chociażby mały, przyczynek „naocznych świadków” tragedii 44-go roku. W szczególności Batalionu „Zośka"32 ze Starówki, najbardziej chyba przetrzebionego.

$\mathrm{Z}$ domu wyniosłam odziedziczoną po rodzinie Czarnockich łatwość pisania. Telefony na dalekich ówczesnych Kresach były rzadkością, więc utrzymywano łączność obszernymi tasiemcami, odczytywanymi wieczorem członkom klanu z ul. Szopena:

3 adresy na tej samej ulicy (trzech nieodłącznych sióstr, plus brata), a ważność owej kolonii podniosła jeszcze obecność Babuni, najstarszej rodem. Odpisywano kolejno i równie szczegółowo. Z młodszego pokolenia chyba tylko ja przyczyniałam się do tej korespondencji.

I nagle, dosłownie niemal z dnia na dzień — koniec. Kompletna jakaś niemożność wypowiedzenia się z czymś bardziej prywatnym, niż... uprzejme wzmianki o pogodzie, czy urodzaju ślimaków w ogródkach. A im potrzeba porozumienia jest bardziej nagląca, im bardziej ów człowiek jest daleki - tym trudniej. To nie tylko jest zupełnie niezrozumiałe dla mnie samej, ale i dosyć przygnębiające. Bo, wracając do początku listu: jak to można wytłomaczyć i usprawiedliwić? Jak zachować kontakt z ostatnimi najbliższymi Mohikanami??

Żeby zakończyć św smutno-jesienny temat nieco kolorowszą nutą (czy może zamazać właściwie tę wystukaną ,prywatność”?) - często przypomina mi się nasz Filipek. Mianowicie: kiedy był jeszcze zupełnie malutki miał zwyczaj włazić pod nasze bardzo nisko zawieszone nad podłogą łóżko. Wystawiał z pod niego pyszczek, — piskliwie ujadał, - i starał się udawać groźne warczenie. I raptem właśnie dosłownie z dnia na dzień, wlazł jak zwykle, ale — do połowy i... ani we wte, ani w tewte. Posłyszeliśmy jego rozpaczliwy płacz $\mathrm{i}$, acz $\mathrm{z}$ trudem, wyciągnęliśmy bez uszkodzenia plecków i sterczącego tyłka. Był tak przerażony, jak i wściekły na łóżko: wyrwał się,

\footnotetext{
${ }^{32}$ Batalion „Zośka” - utworzony pod koniec sierpnia 1943. Przyjął nazwę „Zośka” dla upamiętnienia postaci dowódcy warszawskich Grup Szturmowych Tadeusza Zawadzkiego „Zośki” (poległego w akcji na posterunek graniczny w Sieczychach), podległego Głównej Kwaterze Szarych Szeregów (ZHP). Batalion w większości składał się z podchorążych. Żołnierze Batalionu „Zośka” brali udział w akcjach dywersyjno-sabotażowych, m.in. mających na celu niszczenie kolejowego transportu Wehrmachtu, zaopatrującego front wschodni.
} 
szczekał na nie. Zupełnie nie rozumiał, że to on wyrósł, a nie ono przysiadło mu na złość

Jakże Ci jestem, Jorgene kochany, wdzięczna za Twój tak dobry list. Miałeś wszelako prawo wypiąć się na mnie (jak Filipek z pod łóżka) za to milczenie — „nie chce, to nie i niech się wypcha". Nie tylko, że napisałeś, ale tak serdecznie, jakbyś przeczuwał, że to nie całkowicie moja wina, a na pewno nie brak pamięci i uczucia; chyba głębszego nawet niż ongiś.

Dzięki najserdeczniejsze za książkę ${ }^{33}$ - wspomnienia (że też Ty jeszcze tak dobrze pamiętasz nasz beznadziejnie trudny język!!! Drogi poligloto). Zachowuję jej lekturę na weekend, kiedy mam wolne od codziennych dojazdów do szpitala — bardzo przykrych i męczących. Pewnikiem nie bardziej, niż Twoje poruszanie się „chodakiem", biedaczku. A no - ta metryka, psia kość...

Nie ma kartek świątecznych, tylko polski opłatek. Dzielę się z Wami nim, jak i wspomnieniami Tamtych Czasów — tak odległych, a tak bliskich.

Ściskam Obje z całego serca zawsze Wasza Hanka

Nowaka-Jeziorańskiego znam od dawna. Bywał u nas. Mam jego książki — niezmiernie ciekawe. Widzi mnie się jednym z nielicznych wyjątkowo inteligentnych pisarzy, z którymi Zachód się... liczy. Siedzi w Washingtonie; często jeździ obecnie do Polski (był ongiś „wyklęty”, jak paryska "Kultura”). Pisze wiele; tu i tam. Czy chciałbyś mieć odbitki z co-ciekawszych jego artykułów?

Może zdobędę się (nie na choinkę) na wyciągnięcie z pudełka 3 króli Muzki — chociaż i one budzą za wiele wspomnień...?

13.

[San Francisco] 14-go września [19]95

Kochani, Kochani - jakże bardzo kochani!

Dzwoniła Mildred $^{34}$, żeby podać swój nowy adres i podzielić się wiadomościami o Was (zapisała się na uniwersyteckie studia... historii powszechnej! Lepiej późno niż wcale. Provided, że potrafi się wyciągnąć z tego jakoweś logiczno-aktualne wnioski z zakresu polityki własnego podwórka i białego Dworu). A teraz po tym — nadleciał Twój dobry list; najserdeczniejszy balsam!!

$\mathrm{Na}$ własny temat nie podejmuję się wyszczególniać z takim wdziękiem, jak Ty, kochany (i utalentowany) Jorgenie. Tyle tylko, że: w ostatnich 8-miu latach przyczepiło się do mojej anatomi tyle zahaczających o siebie trabli, że — ani śladu o dawnej Kali. From time-to-time myślę sobie: „no, to już chyba wszystko czym pomysłowy Los może mnie obdarzyć - nogi, oczy, plecki zarejestrowane"... Okazuje się, że jest On znacznie bardziej ode mnie pomysłowy. To hell with him.

Wobec powyższego ograniczam resztki nadwątlonych wysiłków do zachowania przynajmniej minimalnych pozorów anty-współuczuciowych. Ale pisać (w szczególności do Bliskich) — jest mi coraz trudniej. A zawsze myślałam sobie, odstukując w nie-

${ }^{33}$ Książka to Obserwacje duńskiego dyplomaty w Polsce 1939 autorstwa J. L. F. Mogensena, wydana przez Instytut Polsko-Skandynawski w Kopenhadze w 1994 r.

${ }^{34}$ Mildred Schroeder (1918-2014), amerykańska autorka. 
malowane drzewo: jeśli, nie daj Boziu, będę musiała odejść od sztalug — to zostanie taka masa ciekawych wspomień przed-emigracyjnych na moją starą Smith-Coronkę. I - rzeczywiście...

W sumie (co chciałam powiedzieć krótki, a też się nie udało): brak częstrzych wiadomości z nad naszej Zatoki nie ma nic wspólnego z brakiem myśli i tęsknoty do Was, Raczej przeciwnie. Jesteście ostatnimi już Bliskimi, jacy mi jeszcze zostali, a do takowych nie potrafię naciągać owego ,gorsentu pozorów”, Voila.

O polityce - zarówno w Belwederze, jak w Białym Domu ${ }^{35}$ — szkoda gawarit', bo... szlak może trafić, a tego by jeszcze brakowało. Mało lepiej w naszym San Francisco. Od wielu lat „,biali” stanowią zastraszającą minority, spotęgowaną w ostatnich latach manewrami Clintonów ${ }^{36}$ zyskiwania sobie głosów za wszelką cenę (można by rzec Hilary'ious! — gdyby nie świadomość aktualności powiedzonka Wieniawy ${ }^{37}$, tak smutno-aktualnego w zaistniałej sytuacji: „koniec dowcipów — zaczynają się schody”). A ceny są różne: dawni Japończycy zarządzali (i dostali) aż \$ 20 tys. za prewencyjne wakacje w obozach po Per Harbour ${ }^{38}$, a reszta kolorowców wszelkich denominacji (tych niby bez pracy) otrzymują po kilkaset \$\$ od dziecka, więc mnożą się jak króliki. Jeśli zaś chodzi o pracę, to „Chicanos”, jak dotychczas, ograniczają się głównie do agriculture, robiąc jedynie dużo wrzasku, strajków i zamętu (nie mówiąc już, oczywiście, o kosztach policyjnych odstawiania do granicy tych napływających co-nocy „na lewo" i odstawianych z powrotem, w proporcji 500 in-na 50 out). Tyle w wielkim skrócie, o nich.

Natomiast, prawdziwą groźbę dla nieco trzeźwiej przewidujących stali się tacy i inni Azjaci (Koreańczycy, Vietnamczycy, a ostatnio i nawała rodowitych Chińczyków). Za Waszych czasów stanowili oni jeszcze wdzięczną dekorację przyciągającą dolarowych turystów, jak też miejscowych, do czarującego China Town. DZIS - to centrum Mafii, narkotyków itp. crimes z gatunku międzynarodowych, a oplatających całe San Francisco. O dawnych spacerach z pieskiem wieczorową porą — nie ma mowy. Tak, jak nie ma tutaj jednego dnia bez paru gwałtów, napadów, poranień, czy zgoła zabójstw.

To jednak strona medalu ,żółtego niebezpieczeństw” (jak to proroczo przewidywał mój ukochany Oleczek-wujaszek). A druga — ani nie skończyłam listu, ani nie mogłabym go wysłać, bo sama nie dolezę do skrzynki, a podręczni wyjechali na week-end 17-go. Kończę pośpiesznie, bo jutro mam lekarza więc sama wrzucę list do skrzynki w taksówkowym przejeździe -

Otóż ta druga strona medalu (raczej awers, niż rewers — ze względu na skutki): przez ostatnie parę lat Chińczycy opanowali całkowicie już nie tylko podręczne laundrenety, małe restauracje, czy „mama-papa” sklepiki. Z każdym dniem wypychają białych (bez względu na ich poprzednią przynależność krajową) ze wszystkich zawodów: malowanie domów i mieszkań, ogrodnictwo frontowe i patios; restauracje, naprawa dachów i okien, sprzątanie mieszkań — dosłownie wszystko... A przede wszystkim: szpitale,

\footnotetext{
${ }^{35}$ Biały Dom, siedziba prezydenta Stanów Zjednoczonych.

${ }^{36}$ Bill Clinton, prezydent USA (1993-2001).

${ }^{37}$ Bolesław Wieniawa Długoszowski (1881-1942), gen. dyw. (1918-1938), dyplomata, publicysta.

${ }^{38}$ Pearl Harbor, amerykańska baza okrętów na Pacyfiku, na wyspie Oahu, Hawaje. Podczas drugiej wojny światowej 7 XII 1941 r. baza została zaatakowana przez siły japońskie, co spowodowało przystąpienie Stanów Zjednoczonych do wojny.
} 
prywatni lekarze, dentyści. Nursing, sekretariat, laboratories - wyłączność nie do uwierzenia... I nikt nie protestuje przeciw — dyskryminacji Białych.

Nie mam pojęcia po co to wszystko pisałam? Pewnikiem, żeby nie pisać o sobie. A także może i dlatego, że, wychylając się z moich domowych pieleszy jedynie do szpitala czy lekarza, przeskakuję mijający Czas - tak szybki w ogóle, a w naszym wieku specjalnie galopujący.

Kochani - kończę tę chaotyczną epistołkę, dziękując Wam bardzo za pamięć, dobry i bliski list Jorgena, oraz załączone kartki z Svaneke (chociaż na nich odszukiwatam Wasz domek)

Mocno przytulam,

Piszę przez kalkę, bo skończyła się taśma.

I jeszcze, że takiej pogody, jak tegoroczna „najstarsi ludzie...” etc. Myślę, że zima będzie wyjątkowo mroźna. U nas w S.F., temperatura skacze i spada od prawie upału — do prawie przymrozku plus wicher i nocna mgła. Bardzo męczące dla sercowców...

Hanka

U schyłku życia naszych bohaterów w rozmowach stale pojawiał się wątek emerytury i tęsknota za Polską, wolną Polską. Ich marzenia mieściły w ich planach życiowych, w tym życie na emeryturze w Polsce, jako miejscu im najbliższym i najmilszym. Warunkiem było jednak, by Polska była wolna. Okres pobytu na emigracji był wypełniony obawami o przyszłość Polski i w końcu zapanowała radość z odzyskanej przez Polskę wolności. Pozostała jednak troska, co przyniesie najbliższa przyszłość po prawie półwiecznym panowaniu komunistów...

Wówczas brakowało już im sił, by odwiedzić drogie miejsca, nie mówiąc już o powrocie na ojczystą ziemię. Spełniły się marzenia o wolnej Polsce, ale pozostała tęsknota za miejscem rodzinnym, które bezpowrotnie utracili w 1945 roku.

Listy zawierają elementy, które niewątpliwie są uzupełnieniem biografii osób zasłużonych dla ich ziemskiej ojczyzny. Pisownię i podkreślenia pozostawiono jak w oryginale.

\section{LITERATURA}

Archiwum Instytutu Polsko-Skandynawskiego, Kopenhaga. Akta Jørgen i M. Mogensen.

E. S. Kruszewski, Kali czyli magia pędzla, Gazeta Niedzielna 20.04.2003, s. 6; także: Archiwum Emigracji. Studia - Szkice - Dokumenty 2003 z. 5/6, s. 360-362; błędnie podałem rok zgonu 2000, wg Obitury Daily Times USA winno być 1998;

-, Honorowy ambasador, Gazeta Niedzielna 2.04.1989, s. 5-6;

Księga Pamiątkowa Liceum w Olkuszu 1916-1956, Kraków 1957;

J.L.F. Mogensen, Obserwacje duńskiego dyplomaty w Polsce 1939, Kopenhaga 1994;

—, Den store gidseltegning. Sidste akt 1945, Kopenhaga 1996;

Od Moraczewskiego do Składkowskiego. Gabinety Polski odrodzonej 1918-1939, red. J. Faryś, A. Wątor, H. Walczak, Szczecin 2011. 